\title{
LEGAL PROTECTION OF PASSENGER ON ONLINE TRANSPORTATION BASED ON HIGHWAY TRAFFIC ACT
}

\author{
Dwita Pratama1四 \\ ${ }^{1}$ Central Java Regional Police Department \\ $\triangle$ indonesiatama@gmail.com
}

\section{CITED AS}

Pratama, D. (2021). Legal Protection of Passenger on Online Transportation Based on Highway Traffic Act. Journal of Law and Legal Reform, 2(4), 569-590. https://doi.org/10.15294/jllr.v2i4.49351

\section{Submitted: December 7, $2020 \quad$ Revised: March 11, $2021 \quad$ Accepted: July 11, 2021}

\section{ABSTRACT}

Along with the era and technology, the presence of online transportation innovations can be said to be a new thing that can ease the people to use transportation services. The presence of online transportation can be recognized if it fulfills the requirements of the Ministerial Regulation of Transportation Act Number 108 of 2017 concerning the Implementation of Transportation of People with Public Motorized Vehicles Not On Routes. The problem that arises is when this online transportation does not have a transportation operation permit, which then the passengers do not get legal protection for it. The method used is normative juridical where the data used are primary data and secondary data and the data collection used is library research. The data obtained were analyzed qualitatively. From the discussion it can be concluded that 1.Insurance compensation for passengers who have an accident through PT Jasa Raharja is given to an online application-based transportation company that already has a 
transportation operation permit based on the provisions of the Ministerial Regulation of Transportation Act Number 108 of 2017 concerning the Implementation of Public Transportation with Public Motorized Vehicles Not On Routes which is carried out based on Act Number 33 of 1964 concerning the Passenger Accident Compulsory Insurance Fund, for online application-based transportation companies that do not have a transportation operation permit, in the event of an accident the passenger does not receive insurance compensation from PT Jasa Raharja. The responsibility of online transportation service providers has complied with Article 188 of Act Number 22 of 2009 concerning Traffic to compensate for the loss of passengers or shippers due to omission in carrying out transportation and road transportation services as well as Article 19 paragraph (1) of Act Number 8 of 1999 concerning Customers Protection regarding the responsibility of businessmen to provide compensation.

Keywords: Law; Passenger; Online Transportation

\section{INTRODUCTION}

The development of today's era is increasingly rapid, especially in the field of technology. The development of technology also has an impact on progress in various aspects of life, including in the fields of economy and transportation. Transportation is a very important service in supporting the success of development, especially in supporting community economic activities and regional development, both rural and urban areas.

Transportation is a very important field of activity in the life of the people in Indonesia. By realizing the importance of transportation, traffic and public transportation must be organized in an integrated national transportation system which is able to embody the availability of transportation services in accordance with the level of traffic needs and transportation services which are orderly, comfortable, fast, smooth, and low-cost (Muhammad, 1998).

With the construction of transportation facilities, community economic activities and community empowerment, especially in the areas under development with high economic potential will be easier to develop. This community's economic activity will develop if it has a good infrastructure and transportation facilities for accessibility. This accessibility can spur the process of 
interaction between regions to the most remote areas so as to create equitable development.

Online transportation can be recognized as official transportation like public transportation in general if it has complied with the procedures set by the government which requires that every online transportation service provider must be a legal entity and have obtained an operating permit from the government according to the method regulated in the Ministerial Regulation of Transportation Regulation No. 108 of 2017 concerning the Organization of the Transportation of People with Public Motorized Vehicles not on the Route. Based on the provisions of Act 36 to Act 38 of the Ministerial Regulation of Transportation Number 108 of 2017 concerning the Organizing of Transportation for People with Public Motorized Vehicles not on the Route, which in order to organize the transportation of people not on the route, a permit must be obtained.

Online transportation is usually widely used by residents in big cities because of the advantages of online transportation compared to conventional transportation, which is faster and easier to access, this is very easy for the community, because people can access it anywhere and anytime without the need to come to where the public transport operates or stops by. Related to this, usually the public transportation operated around the relatively busy intersection or around shopping centers and at the entrances to residential areas. With the rapid development of technology, all data matters are done using internet which can be accessed using a cellphone so that it makes us easily and quickly to get the information, one of which is online transportation.

Nowadays in Indonesia there are online transportation services such as GOJEK and GRAB which allow prospective passengers not to come to the public transportation station, meanwhile the prospective passengers simply could order through an application on their smartphone then the online transportation will come to pick up. Not only that, the online transportation can also reduce congestion, especially in big cities. This lifestyle change is used by businessmen to start a competition in the online transportation business.

The existence of the company's business providing online transportation application facilities is regulated in the Ministerial Regulation of Transportation Act Number 32 of 2016 concerning the Implementation of Public Transportation with Public Vehicles Not on Routes. The regulation is very limited only in determining tariffs, data access and monitoring, form of company, and payment system which must be adjusted to Act Number 19 of 2016 concerning amendments to Act Number 11 of 2008 concerning Electronic Information and 
Transactions. This Ministerial Regulation of Transportation also only provides a legal support for the existence of companies that provide online transportation application facilities with four-wheeled transportation modes only.

This is based on the concerns conveyed by the Minister of Transportation in various mass media, both print media and television, with respect to safety collateral of two-wheeled transportation modes. In Act No. 22 of 2009 concerning the Traffic and Transportation, it is also regulated that two-wheeled vehicles are not allowed to be used as public transportation. It is clear to be said that companies providing online transportation application facilities that use two wheels as their transportation fleet have no existence towards the jurisprudence or the eye of law.

Take into account the important and strategic role of traffic and transportation which controls the livelihood of many people, the construction and development of transportation infrastructure and facilities needs to be organized and developed in an integrated system and the interests of the public as the user of transportation services need to get prioritized with optimal services from both the government and transportation service providers (Warpani, 1990). In addition, legal protection for the rights of the public as transportation users must also get determination.

In fact, in many previous research and studies, the accident rate in Indonesia is still relatively high when compared to other countries, even in several big cities in Indonesia such as Jakarta, Medan, Surabaya, Yogyakarta, Semarang, the accident rate is high (Wayne, 2020; Sari, 2020; Fakhrudiyanto, 2017; Trisnawati, 2017). Various efforts have been made by various parties, ranging from public education to strengthening the traffic police, to the application of strict and electronic-based sanctions. However, protection for victims of traffic accidents, especially users of online transportation services, is still inadequate (Farid, 2019; Agreda, 2017; Nugraha, 2020; Setiawan, 2020).

Based on the description of the background above, the author will discuss things as follows:

1) Do users of 4 (four) wheeled online transportation services get Jasa Raharja insurance if they get a traffic accident?

2) What is the form of responsibility for 4 (four) wheeled online transportation service providers in the event of a traffic accident to its passengers?

The benefits that can be obtained from this research include:

1) Theoretically, to contribute ideas in the context of developing knowledge in the field of law and especially in the field of online-based transportation; 
2) Practically, it is expected to provide information and knowledge to the government, online-based transportation companies, and the public regarding the legal position of online-based transportation and the responsibilities and procedures for users of online transportation services that may arise.

\section{METHOD}

This research uses normative and empirical research. The research method uses a regulatory, conceptual, sociological, and analytical approach. The sources and types of materials used in this study consist of literature sources, and secondary legal materials. The data obtained were analyzed qualitatively.

\section{LEGAL PROTECTION CONCEPT}

Legal protection consists of 2 (two) syllables, namely "protection" and "legal" which means "providing protection according to the applicable law is a State of $L a w^{\prime \prime}$, meaning that the administration of the state in all fields must be based on the rule of law that is fair and certain so that it is not solely based on political power. Furthermore, Article 28D paragraph (1) of the 1945 Constitution of the Republic of Indonesia states that "Everyone has the right to law enforcement, legal collateral, legal protection, and legal determination. Regarding to this, legal relations, legal guarantees, and legal collateral given to every citizen must be based on the principles of justice and legal equality (Suprayogi, 2018).

The definition of legal protection is also explained by several experts, including:

1) Satjipto Rahardjo defines legal protection as an effort to protect one's interests by allocating a power to them to act in the context of their interests (Rahardjo, 2003).

2) Philipus M. Hadjon defines legal protection as a body of regulations that will protect one thing from another. Related to the customers, it means that the law provides protection for the rights of customers which results in the nonfulfillment of the customers rights (Hadjon, 1987).

The importance of legal protection for customers is due to the weak wheel and deal position of customers. Legal protection is needed in competition and the number of products and services that place customers in a weak wheel and deal position. Broadly speaking, customers rights are divided into three 
rights which are the basic principles according to Article 4 of Act Number 8 of 1999 concerning Customers Protection, namely:

1) Rights intended to prevent customers from personal loss, as well as property loss;

2) Rights to obtain goods and/or services at fair prices; and

3) The right to obtain an appropriate solution to the problems at hand.

Related to this, when the customers expect to be protected, their rights must be fulfilled either by the state and the businessmen, since the fulfillment of the customers rights will protect them from losses through various aspects (Suprayogi, 2018).

\section{TYPES OF LEGAL PROTECTION}

An important legal protection to be developed in a sustainable manner, this is in order to provide collate rate to the public in getting protection based on the laws and regulations applied in Indonesia. The Indonesian state itself recognizes two kinds of legal protection, according to Philipus M. Hadjon legal protection for the people includes two things, which are (Hadjon, 1984):

a) Preventive legal protection, which is a form of legal protection where the people are given the opportunity to submit their objections before the government decision gets a definitive form.. The goal is to prevent disputes. In Indonesia, there is no specific regulation regarding to preventive legal protection.

b) Repressive Legal Protection, which is a form of legal protection that is more aimed at resolving disputes. Repressive legal protection in terms of protection for customers can be done through:

\section{1) Sentencing}

2) Sanctions

In general, compensation claim for customers losses as a result of the use of products or services, whether in the form of material, physical, or mental losses, can be based on the provisions that have been mentioned, which in general there are only two categories, that is claims for compensation based on breach of contract and claims for compensation based on acts against the law (Miru, 2013).

The provisions of Article 62 of Act Number 8 of 1999 concerning Customers Protection, which states that "Criminal prosecution can be carried out against business actors and/or their management." This provision clearly 
shows a form of criminal liability which is not only imposed on the management but also on the company. According to Nurmadjito, this is an effort aimed at creating a system for customers protection and through this provision the company is declared a subject of criminal law (Miru, 2013).

Administrative sanctions are not aimed at customers in general but rather to entrepreneurs, both producers and distributors of their products. Administrative sanctions are related to permits granted by the government of the Republic of Indonesia to such entrepreneurs or distributors. In this case, if there is a violation, the permits can be revoked by the government unilaterally.

\section{ONLINE TRANSPORTATION CONCEPT AND LIMITATION}

The word transportation is defined by the Black Law Dictionary as the removal of goods or persons from one place to another by a carrier, which in Indonesian is more or less defined as the movement of goods or people from one place to another by using a vehicle. The next word is the word online which in Indonesian is often translated as in the network, or better known as the abbreviation "daring". The meaning of online is a condition when a computer is connected to internet network (Wijaya, 2014). The definition of online transportation is an internet-based transportation services in every transaction, starting from ordering, monitoring lanes, payments and evaluating the service itself (Pratama, 2016). Online transportation is one form of traffic and transportation organizers that runs by going along with and taking advantage of the technology development.

Several types of online application-based transportation service companies in Indonesia:

a) Go-Jek

Go-Jek is a service provider company engaged in technology and onlinebased transportation (Pratama, 2016). In addition to serving passenger pick-up (Go-Ride), Go-Jek also serves goods delivery (Go-Send), food ordering (Go-Food), and several other services. The presence of Go-Jek facilitates community mobility and helps to reduce unemployment through creating new job vacancies as becoming a Go-Jek driver. Fundamentally, Go-Jek works by taking the requests of passengers and connect it with the nearby online motorbike services operating around 
the same area, simply by downloading the application from the Play Store prior to that until then we can order these services. Transportation fares are adjusted according to the distance traveled. In addition to passenger transportation services, there are also goods delivery services or couriers and shopping.

b) Grab

Grab is a competitor app Gojek. The operating system and features offered are almost the same as Go-Jek. Some of the features that can be accessed in the application Grab among others, GrabBike, GrabCar, GrabTaxi and Grab Express. The payment methods offered are quite attractive, namely through cash, credit cards, and mobile wallets (Prasetyowati, 2018).

Furthermore, Based on the provisions of Article 1 number 25 of Act Number 22 of 2009 concerning Traffic and Transportation, what is meant by passengers are: "People who are in a vehicle other than the driver and crew of the vehicle". Fundamentally, according to the above definition, what is meant by passengers are in a public vehicle other than the driver and the officer in charge of the vehicle. Apart from being regulated in Article 1 number 25 of Act Number 22 of 2009 concerning Traffic and Transportation, it is also regulated in Article number 22 in which the service users are individuals or legal entities who use the services of public transportation companies.

\section{BUSINESSMAN OF ONLINE TRANSPORTATION}

Economic development is largely determined by the success of the real sector. To achieve the success in the real sector, it is necessary to empower the economic businesses that involve the businessmen themselves. According to Act Number 8 of 1999 concerning Customers Protection, businessmen are:

"Businessman is any individual or business entity, whether in the form of a legal entity or illegal entity established and domiciled or conducting activities within the jurisdiction of the Republic of Indonesia, either by itself or mutually through an agreement to carry out business activities in various economic fields."

Based on the explanation in the provisions of Article 1 point 3 of Act Number 8 of 1999 concerning Customers Protection, it is said: Businessmen included in this definition are companies, corporations, cooperatives, BUMN, importers, traders, distributors, and others (Krisyanti, 2008).

The circumstance of online transportation businesses such as Go-Jek, 
Grab, and so on is to provide transportation services or services to all elements of society. Capturing the widest possible number of customers from the community is the target of online transportation businessmen (Wijaya, 2016).

The realization of the transportation business carried out by online transportation business actors gives rise to a legal agreement with passengers. In this case, online transportation business actors enter into transactions in the form of an agreement to provide transportation services, which transactions are carried out through electronic methods, which give rise to rights and obligations for both parties. Online transportation business actors give rights to passengers for certain transportation services or services, and on the other hand raises the right to rewards or tariffs for online transportation business actors. Online transportation business actors carry out their obligations in the form of providing transportation services or services (Wijaya, 2016).

The position of online transportation business actors is not limited to the existence of a legal relationship with passengers of online transportation services. Online transportation business actors are legal subjects when business actors enter into partnership agreements with online transportation drivers, work agreements with employees of online transportation companies, agreements with other companies, and other agreements.

\section{LEGAL PROTECTION FOR CUSTOMERS IN USING ONLINE TRANSPORTATION SERVICES}

Legal Protection for customers in using online transportation services in this globalization era, the relationship between businessmen as the online transportation service provider with the customer is becoming closer and more open. The intervention of the state, cooperation between countries and international cooperation are needed. Legal protection for customers in Indonesia has been regulated in Act Number 8 of 1999 concerning Customers Protection. Legal protection given to application-based transportation service businessmen which in terms of transportation has been regulated in Article 10 of Act Number 22 of 2009 concerning Traffic and Transportation, Government Regulation Number 41 of 1993 concerning Traffic and the Decree of the 
Transportation Minister Number 35 of 2003 concerning the Implementation of Public Transportation on the Road.

By that way, the government will permit the businessmen of online transportation services after they have completed the terms and conditions, they are required to register their drivers in the form of a business entity because it has been legalized by the government. So, then the online transportation can already be operated across the regions in Indonesia (Putra, 2012).

In the further context, if the customer feels that the quantity and quality of the service is inappropriate, then the customer has a right to receive compensation in accordance with the provisions of Article 19 paragraph (1) and paragraph (2) of Act Number 8 of 1999 concerning Customers Protection which states that (Kristiyanti, 2011):19

a. Article 19 Paragraph (1)

Businessmen are responsible for providing compensation for destruction, pollution, and or customers losses due to consuming goods and/or services that are produced and/or traded.

b. Article 19 paragraph (2)

The compensation as referred to in paragraph (1) can be in the form of refunds or replacement of goods and/or services of a similar or equivalent value, or health care and/or compensation in accordance with the provisions of the prevailing laws and regulations.

The losses that can occur towards the implementation of online motorbike services are as follows (Rahmatullah, 2018):

1) Accident

Accident is a risk that must be faced by the road users, either who use private vehicles or public transportation services. Accidents may happen to online motorbike service users since those users will never know when the mischance will come which then may result in minor or major injuries

2) The Ordered Goods is Damaged or Lost

The goods that have been dealt may be damaged or lost due to intentional, abnormal or unintentional unwanted event. Whatever the reason for the online motorbike services, the parties concerned must be able to compensate for this form of loss in accordance with a mutual agreement in order to obtain justice for each of the parties involved.

3) The ordered goods do not reach the customers in which this kind of incident is most likely to happen. 


\section{TRAFFIC ACCIDENT AND THE LEGAL PROTECTION FOR THE VICTIM}

Traffic is very closely related to what is called as transportation, it is due to the definition of traffic itself according to Article 1 point 2 of Act Number 22 Year 2009 concerning Traffic and Transportation, it is stated: "the movement of vehicles and people in the street". Therefore, while in street we all must comply with the regulations made by the government, so that we can use the transportation on the highway more safely and avoid an accident.

Traffic accidents often happen and is always not expected to happen by all the transportation users in Indonesia as well as in other countries. It is considered as a mischance that must be avoided either by the motorized and non-motorized vehicle drivers and pedestrians who sometimes would become the victim. Based on Article 1 number 24 of Act 2009 Number 22 concerning Traffic and Transportation defines the traffic accident as an incident on the road which is unexpected and unintentional involving the vehicle with or without the other road users so that resulting in human casualties and/or property loss.

Traffic accidents often occur in the street and according to Article 229 of Act 2009 Number 22 concerning Traffic and Transportation, accidents are classified into 3, they are (Adji, 2015):

1. Minor Traffic Accident

Article 229 Paragraph (2) Act Number 22 concerning Traffic and Transportation states that: "Minor traffic accident as referred to paragraph (1) is an incident which damages the vehicles/goods." Due to this, basically the result of minor accident is only limited to damage the vehicle or goods involved in the accident that occurs.

2. Moderate Traffic Accident

Article 229 paragraph (3) Act Number 22 concerning Traffic and Transportation states that: "Medium Traffic Accidents as referred to paragraph (1) C are an accident that results in minor injuries or damages." While what is defined by minor injuries here are injuries that result in the victim to require hospitalization or other than those classified as serious injuries.

3. Fatal Traffic Accident

Article 229 paragraph (4) of Act Number 22 concerning Traffic and Transportation states that: "Fatal traffic accident as referred to in paragraph 
(1) $C$ is an incident that results in serious injury or death towards the victim. Basically, in an accident that causes the victim dead or seriously injured, it is called as fatal traffic accident, and here what is meant by serious injury is an injury that results in the victim:

1) Falling sick and with no hope of recovery at all or vulnerable to die;

2) Unable to continuously carry out the current position or job;

3) Loss of one of the five senses;

4) Suffer from severe disability or paralysis;

5) Disturbed mind for more than 4 (four) weeks;

6) Miscarriage

7) Wounds which need hospitalization for more than 30 (thirty) days.

Furthermore, the compensation for traffic accidents also has been stipulated in some provisions. Based on the provisions of Article 1 paragraph 3 of the Ministerial Regulation of Finance Number 15/PMK.010/2017 concerning Compulsory Compensation and Contributions by the Accident Insurance towards the Passengers of Public Transportation either on Land, River/Lake, Shipping, Water, and Air, the definition of compensation is amount of money given to passengers who become the victim in an accident of public transportation either on land, rivers/lakes, ferries, Water, and air. All passengers who become victims or their heirs are insured or guaranteed by Act Number 33 of 1964 in which PT. Jasa Raharja are responsible to give the passengers rights of submitting a request for compensation due to an accident happened to them. PT. Jasa Raharja insures and guarantees all the passengers. If the accident occurs and results in losses like death, permanent disability, or injury to the passenger insured, their loss must be replaced by PT. Jasa Raharja as the insurer (Muhammad, 2011).

Asuransi Sosial Kecelakaan Penumpang (ASKEP) is regulated in Act Number 33 of 1964 concerning the Fund of Traffic Accident Insurance so then this Act and its implementations become the basic regulation for the application of Asuransi Sosial Kecelakaan Penumpang (ASKEP). Asuransi Sosial Kecelakaan Penumpang (ASKEP) is a type of compulsory or mandatory insurance. It is said to be a mandatory insurance because (Muhammad, 2011).

1) Asuransi Sosial Kecelakaan Penumpang (Askep) is applied since it is required by the law, not by a casual agreement. The law itself is entitled as Dana Pertanggungan Wajib Kecelakaan Penumpang;

2) The organizer of this insurance is the government in which is delegated to the State-Owned Enterprises; 
3) Asuransi Sosial Kecelakaan Penumpang (Askep) has a motive as a community protection (social security) whose funds are collected from the community and used for the people who face an accident;

4) Funds that have been collected from the community but have not been used as the accident funds are used for community welfare through investment programs.

Article 2 of 1964 Act Number 33 concerning the Compulsory Fund for Accident Coverage towards Passenger Accidents stipulates that the legal relationship between the passenger and the insurance party is created by the payer of the contribution and the fund manager. Based on this provision, it can be understood from the perspective of insurance law in which the owner of the fund is the insurer, while the contributors are the insured. The owner of the fund as the insurer bears the risk of passenger accidents that may also occurs to the contributors who are the insured.

The contribution payers as the insured are regulated in Article 3 of Act Number 33 of 1964 concerning Mandatory Insurance Funds to Passengers Accident stipulates that every legitimate passenger from public motorized vehicles, trains, aircraft, and ships of national companies is obliged to pay the dues through the entrepreneur/owner of the company in concern of covering the financial consequences caused by the passengers accidents. However, the passengers of public motorized vehicles in town are exempted from paying the mandatory dues. Based on this provision, it is clear that the person insured is each the legitimate passenger and is also obliged to pay dues through the transportation company concerned, except for passengers of transportation within the city.

In insurance law, premise is a sum of money paid by the insured to the insurer in return for the risk they bear (Muhammad, 2011). Asuransi Sosial Kecelakaan Penumpang (ASKEP) is an insurance, then in this party it also has some amount of premises. The contributions as premises for Asuransi Sosial Kecelakaan Penumpang (ASKEP) must be paid along with the payment of the relevant public passenger transportation costs.

The entrepreneur/owner of the related passenger of public transportation is obliged to account for all the results of the mandatory levy on their passengers and deposit it to the insurer, which is PT. Asuransi Jasa Raharja periodically every month, no later than 27 th directly or through a bank or other insurance agency appointed by the Minister of Finance

The victims who have rights to receive compensation from PT. Jasa Raharja (Persero) are as follows (Salamanda, 2008): 
1. According to Act No. 33 of 1964 Article 3 paragraph 1, it is stated that compensation is given to legitimate passengers from the public motorized vehicles, trains, airplanes, national companies and ships of national shipping companies;

2. According to Act No.34 of 1964 Article 4 paragraph 1 in conjunction with Article 10 of Government Regulation No. 18 of 1965, it is explained that the person who has rights for compensation is anyone who becomes a victim of death/permanent disability due to an accident caused by any transportation.

The amount of Jasa Raharja compensation for the victims of accident (Pratama, 2021):

1. Compensation for death: IDR 50 million

2. Permanent disability compensation (maximum): IDR 50 million

3. Maintenance compensation (maximum): IDR 20 million for land and water transportation users and IDR 25 million for air transportation users

4. Compensation for reimbursement of funeral costs if the victim has no heirs: IDR 4 million

5. Compensation for additional benefits (first aid fee reimbursement): IDR 1 million

6. Compensation for additional benefits (ambulance reimbursement): IDR 500,000.

Meanwhile the rights for compensation would become invalid/expired if:

1. The request is submitted after 6 months of the accident.

2. No collection is made within 3 months after the said matter is approved by Jasa Raharja.

Compensation is given to the heirs with the following priority scale:

1. Legal Widow/Widower

2. Their legitimate children

3. Their legitimate parents

4. If there are no heirs, then the funeral costs will be reimbursed to the one who organized it. 


\section{GRAB ACCIDENT INSURANCE CLAIM PROCESS FOR PASSENGERS}

Grab as an application service provider for online transportation available in Southeast Asia provides the best protection for users in accordance with its mission of providing safe public transportation.

\section{GRAB ACCIDENT INSURANCE FOR PASSENGERS}

Grab drivers and passengers are required to agree upon the declaration of protection provided in the form of accident insurance and then the victim will have rights to be immediately treated at the nearest hospital. Because it is not in the form of health insurance, the reimbursement of the claim given is in the form of the first medical expenses immediately after the accident occured. This coverage or protection is provided from the period of time when the Grab partner receives the order until the trip is complete.

That's why it's so important to get immediate medication on the day of the accident. In addition, the Grab accident insurance claims the process for the injured passengers and must be done at a hospital, clinic, or by visitting the available health facility. If you go to get the medication other than at the places appointed, you will get rejected by the time of submitting the claim.

\section{When You Need a Letter of Reference}

There are times when the patient needs a referral letter. This happens if the doctor or health facility manager states that the clinic is not adequate for the patient medication and care. Furthermore, the referral letter must be submitted to the hospital that has adequate facilities.

\section{Save The Receipt}

Another important thing to do is to keep the proof of payment receipt for the medication made at the healthcare center or facility. The receipt must have a stamp and signature from the relevant clinic / hospital / doctor attached by their practice license number. 


\section{The Rejected Insurance Claim}

It should be understood that there are some accidents which its medical expenses are actually the driver's burden. This thing will happen if the accident occurs due to the carelessness of the driver. For example, by breaking through the railroad gate, breaking through when the traffic light is red, reckless, and so on. So for those who work as drivers should be careful in this case.

On the other hand, if the accident occurs due to the carelessness of the passenger, the final result will be the same where the insurance claim will not be processed by the respective online transportation provider or Grab in this case. The example of passengers carelessness in using Grab Car is by not using the safety belt. Meanwhile in riding the Grab bike, the passengers do not lock the helmet strap or sit sideways.

Besides that, for both parties either the driver or the customer is that if they have different self-information while on the running transportation order. However, if during the inspection it can be proven that the victim was indeed a passenger when the accident occurred, Grab can provide insurance according to the rules that have been set.

\section{Submission Time of The Insurance Claim}

The completeness of data is also one of the conditions that must be met if you want to submit the insurance claim for Grab passenger and to be processed afterwards. The completeness of this data must be ensured within the $\mathrm{H}+7$ period from the date of the accident occured. Meanwhile, the accident report must done on the same day when the accident occurred. If it has passed the grace period during the process of completing the documents, the claim will not be processed.

\section{COMPLETE DOCUMENTS OF GRAB ACCIDENT INSURANCE CLAIM PROCESS FOR THE PASSENGERS}

The Grab accident insurance claim process for the injured passengers must include documents that will support the facile process of getting the claim. Here are some documents that you must prepare:

a) Prepare the claim submission paper that must have been by the party who is making the accident report. If the passenger has received medication or care from a hospital or other healthcare center, then notify the passenger to make a claim via email at the address: support@grab.com or you can also call the customer service at 021-80648777. 
b) Complete the claim paper with the driver's identity card, as well as identification belonging to the passenger who was the victim of the accident.

c) Have the passenger's booking ID number included

d) In the document filing a claim it is mandatory to include photos of the accident. For example, the photos of victims or drivers who were injured and photos of the vehicles to claim for the damage. This photo is useful as one of the complementary evidences that it is true if an accident has occurred.

e) Attach the original medical receipt, not a photocopy, with the exact date and official stamp of the healthcare center where the victims get the medication.

f) Attach the claim file and other medical test proof such as laboratory results or X-rays, if any.

g) If the passenger died, a post-mortem is required with an explanation of what has caused the death.

\section{JASA RAHARJA INSURANCE COVERAGE FOR GOCAR SERVICE}

When you are travelling with GoCar, you will automatically get insurance benefits. Premium costs (Mandatory contributions) are included in the trip fees.

\section{Benefits and coverage value can I get from this insurance}

The amount of benefit and the coverage value in accordance with the Ministerial Regulation of Finance Number: KEP.15/PMK.01 /2017 as dated February 13, 2017:

\begin{tabular}{ll}
\hline Insurance Benefit & Benefit coverage \\
\hline Death by accident & IDR50.000.000 \\
Permanent Disability (Maximum) & IDR50.000.000 \\
Medical expenses (Maximum) & IDR20.000.000 \\
Burial Reimbursement Cost (Does not have an heir) & IDR4.000.000 \\
Additional Benefits of First Aid Costs Reimbursement & IDR1.000.000 \\
Additional Benefits of Ambulance Fee Reimbursement & IDR500.000 \\
\hline
\end{tabular}

\section{Who is covered by this insurance?}

The eligible parties for this insurance are:

- Passengers who are in the vehicle 
- Four (4) passengers who are in GoCar and up to six (6) passengers for GoCar L

- Driver partner. Detailed information for driver-partners can be clicked here

- Third parties outside the vehicle who is involved in the accident

\section{How do I submit a claim?}

a. Claim through PT. Jasa Raharja's official channel:

1. Contact PT. Jasa Raharja at Call Center 1500020 or SMS Center 081210500500

2. Jasa Raharja will direct your report to official reporting channels, including the JRku smarthphone-based application, Jasa Raharja Website, or go directly to the nearest Jasa Raharja branch

3. PT. Jasa Raharja will record the accident report

4. Service Officer of PT. Jasa Raharja will contact the Gojek to verify the data

b. Direct claim to Gojek Customer Service

1. Report the accident by email to criticalops@gojek.com, by providing information that includes name, phone number, police number, and accident location.

2. The SOS Team will escalate the report to Incident Response Team (IRT) and verify it according to the internal SOP

3. The IRT team will coordinate with PT. Jasa Raharja

\section{Is there a deadline for signing up a claim?}

PT. Jasa Raharja may reject the customer's request for an insurance claim if the request exceeds 6 (six) month deadline since the accident occurred (Article 16 and Article 18 paragraph (1) a Government Regulation No. 17/1965).

\section{How long does it take to process the claim?}

1. The claim settlement process for either injured or death is until the payment can be completed in a maximum of 1 (one) hour since the submission of complete documents needed.

2. In the case of filing death by accident claim, then the maximum completion of claim is 4 (four) days from the date of the accident occured.

3. In the case of injured victims whose their hospital bill have been insured, the completion of claim is 7 (seven) days maximum after the bill sent. 


\section{Insurance Claim Exclusions}

Based on Government Regulation (PP) 13 No. 17/1965 concerning Provisions for the Implementation of Compulsory Coverage Funds, the passengers insurance claim will become invalid or rejected if some conditions occurred:

1. The victim has received a Mandatory Contribution guarantee under the Act $34 / 1964$ so it means that they are unable to make a double claim.

2. Suicide, suicide attempt or other intentions on the part of the victim, including the consequences arising from the murder, attempted murder, hijacking, robbery, and the like are also not covered by PT. Jasa Raharja

3. Accidents due to the drunk/unconscious victims, committing criminal acts, or accidents arising because the victims have physical/mental disabilities.

4. Accidents that are not related to the risk of modern traffic or accidents due to the use of vehicles other than their common function as public transportation, such as:

a) street race.

b) an accident due to natural disasters.

c) accidents due to war, occupation, civil war, rebellion, riots, strikes, terrorism, political turmoil or other community chaos.

d) accident due to weapons used during a war.

e) accident due to acts ordered by the armies or TNI.

f) If the request for compensation claims has passed the 6-month.

\section{CONCLUSION}

This study concluded that apart from being regulated in Article 1 number 25 of Act Number 22 of 2009 concerning Traffic and Transportation, it is also regulated in Article number 22, which says that the service users are an individual or can be any legal entity who uses the services of public transportation companies. The passenger losses that must be covered by PT. Asuransi Jasa Raharja as the insurer are the accidents that actually occur and are not caused by any carelessness and result in losses like death, permanent disability, or injuries suffered by passengers as the insured. Compensation is given if the passenger concerned is inside or riding the transportation when the accident occured, or in other words the passengers are on board from the place of they have been picked up to getting off at the destination. Insurance compensation for passengers who have an accident through PT. Jasa Raharja is given to an online application-based 
transportation company that already has a transportation operation permit based on the provisions of Ministerial Regulation Number 108 of 2017 concerning the Implementation of People Transportation with Public Motorized Vehicles Not On Routes which its implementation is based on Act Number 33 of 1964 concerning the Mandatory Insurance Fund for The Passengers Accident, if they have an online application-based transportation that do not have a transportation operation permit, if an accident occurs, the passengers will not receive insurance compensation from PT Jasa Raharja. The responsibility of online transportation service providers or online application-based transportation companies has complied with Article 188 of Act No. 22 of 2009 concerning Traffic to compensate for the loss of passengers or couriers due to carelessness in carrying out the vehicles. In Article 19 paragraph (1) Act Number 8 of 1999 concerning Customers Protection regarding the responsibility of the businessman to provide compensation for the damage, injury and/or customers loses in consuming the goods and/or services produced or traded. The form of responsibility for the online transportation service providers for passengers who get an accident are the provision of compensation in the form of compensation to the heirs of passengers who die in the accident as well as the health care to passengers who suffer from physical disabilities and injuries due to transportation accidents that occurred.

\section{REFERENCES}

Adji, A. P. (2015). Tanggung Jawab PT.Jasa Raharja dan Perusahaan Pengangkutan PO. Sumber Sejahtera Terhadap Penumpang Korban Kecelakaan. Jurnal Ilmu Hukum Legal Opinion, 3(3).

Agreda, S. (2017). Optimalisasi Penindakan Pelanggaran Lalu Lintas Terhadap Modifikasi Kendaraan Bermotor Yang Menyebabkan Kecelakaan Lalu Lintas Di Wilayah Hukum Polres Purbalingga. Advances in Police Science Research Journal, 1(2), 521-566.

Bagus, R. P. P., \& Gede, P. A. I. (2016). Perlindungan Hukum Terhadap Konsumen Dalam Menggunakan Jasa Transportasi Online Uber Dan Grab di Indonesia, Jurnal Kertha Semaya 4(3).

Fakhrudiyanto, N. (2017). Peran Unit Dikyasa Satuan Lalu Lintas Polres Purworejo dalam Menekan Angka Kecelakaan Lalu Lintas. Advances in Police Science Research Journal, 1(1), 195-244. 
Farid, I. (2019). Implementasi Program Safety Riding Dalam Mencegah Kecelakaan Lalu Lintas Terhadap Pelajar Di Kabupaten Karawang. Police Studies Review, 3(12).

Hadjon, P. M. (1987). Perlindungan Hukum Bagi Rakyat di Indonesia. Surabaya: Bina Ilmu.

Krisyanti, C. T. S. (2008). Hukum Perlindungan Konsumen. Jakarta: Sinar Grafika.

Miru, A. (2013). Prinsip-Prinsip Perlindungan Hukum Bagi Konsumen di Indonesia. Jakarta: Raja Grafindo Persada.

Miru, A., \& Yodo, S. (2008). Hukum Perlindungan Konsumen. Jakarta: Raja Grafindo Persada,

Muhammad, A. (1998,). Hukum Pengangkutan Niaga. Bandung: PT. CitraAditya Bakti.

Muhammad, A. (2011). Hukum Asuransi Indonesia. Bandung, Citra AdityaBakti.

Nasution, K. (2016). Penerapan Prinsip Tanggung Jawab Pengangkut Terhadap Penumpang Bus Umum, Mimbar Hukum, 26(1).

Nugraha, L. S. (2020). Efektivitas Program Safety Riding Guna Menekan Angka Kecelakaan Lalu Lintas di Polres Cianjur. Indonesian Journal of Police Studies, 4(12).

Pratama, G. Y., et.al. (2016). Perlindungan Hukum Terhadap Data Pribadi Pengguna Jasa Transportasi Online Dari Tindakan Penyalahgunaan Pihak Penyedia Jasa Berdasarkan Undang-Undang Nomor 8 Tahun 1999 Tentang Perlindungan Konsumen. Diponegoro Law Journal, 5(3).

Rahardjo, S. (2003). Sisi-sisi Lain dari Hukum di Indonesia. Jakarta: Kompas. Rahmatullah, M. (2018). Kedudukan Hukum Transportasi Online Menurut Hukum Pengangkutan di Indonesia (Studi di Kota Mataram). Thesis. Mataram: Universitas Mataram.

Republic of Indonesia. (1964). Undang-undang Nomor 33 Tahun 1964 Tentang Dana Pertanggungan Wajib Kecelakaan Lalu Lintas (Lembaran Negara Republik Indonesia Tahun 1964 Nomor 137, Tambahan Lembaran Negara Republik Indonesia Nomor 2720).

Republic of Indonesia. (1999). Undang-Undang Nomor 8 Tahun 1999 tentang Perlindungan Konsumen (Lembaran Negara Republik Indonesia Tahun 1999 Nomor 42, Tambahan Lembaran Negara Republik Indonesia Nomor 3821).

Republic of Indonesia. (2009). Undang-Undang Nomor 22 Tahun 2009 tentang Lalu Lintas Dan Angkutan Jalan (Lembaran Negara Republik Indonesia Tahun 2009 Nomor 96, Tambahan Lembaran Negara Republik Indonesia Nomor 5025). 
Republic of Indonesia. (2017). Peraturan Menteri Perhubungan Nomor 108 Tahun 2017 tentang Penyelenggaraan Angkutan Orang Dengan Kendaraan Bermotor Umum Tidak Dalam Trayek (Berita Negara Republik Indonesia Tahun 2017 Nomor 1474)

Salamanda, V. R. (2008)). Penyelesaian Ganti Rugi Akibat Kecelakaan Kendaraan Bermotor Roda Dua. Undergraduate Thesis. Jember: Universitas Jember.

Sari, H. W. (2020). How Does the Traffic Community Education Unit (Dikmas Lantas) Reduce Student Traffic Violations?. Tanggon Kosala, 9(2), 225-256. Setiawan, R. A. (2020). The Role of the Traffic Education Community Unit in Minimizing Traffic Violations in Cirebon Police Department. Tanggon Kosala, 9(1), 75-86.

Suprayogi, I. (2018). Perlindungan Hukum terhadap Penumpang Transportasi Online Apabila terjadi Kecelakaan Menurut UU No. 33 Tahun 1964 Tentang dana Pertanggungan Wajib Kecelakaan Penumpang, Undergraduate Thesis, Jember: Universitas Jember.

Trisnawati, S. S. G. (2017). Upaya Penindakan Pelanggaran Unit Turjawali Satuan Lalu Lintas Polres Klaten untuk Mengurangi Pelanggaran Lalu Lintas Pada Kalangan Pelajar. Indonesian Journal of Police Studies, 1(2), 773-774.

Utomo, H., Jonemaro, E., \& Ananta, M. (2017). Perbandingan Usabilitas Aplikasi Taxi Online Android (Grab-car dan Uber) Menggunakan Unified Theory of Acceptance and Use of Technology (UTAUT).Jurnal Pengembangan Teknologi Informasi Dan Ilmu Komputer, 1(12), 1708-1717

Wayne, A. M. (2020). Efektivitas Penerapan E-Tilang dalam Penindakan Pelanggaran Lalu Lintas di Wilayah Hukum Polres Banyumas. Police Studies Review, 4(1), 57-120.

Wijaya, A. (2016). Aspek Hukum Bisnis Transportasi Jalan Online. Jakarta: SinarGrafika. 